\title{
E-Learning Implementation Barriers during COVID-19: A Cross-Sectional Survey Design
}

\author{
Ishaq Al-Naabi and Abdullah Al-Abri \\ English Language Centre, University of Technology and Applied Sciences, \\ Nizwa, Oman \\ https:// orcid.org/0000-0001-8829-2922 \\ https://orcid.org/0000-0001-7198-9643
}

\begin{abstract}
Most higher education institutions have embraced emergency remote teaching (ERT) as a response to school and university closures due to the Covid-19 pandemic. We used a cross-sectional survey design to examine teachers' views on the implementation of e-learning for ERT due to Covid-19 in Omani higher education. We examined four barrier categories: teacher-related, institutional-related, curriculum-related and student-related. We also assessed the relationship between these barrier levels and measured the differences between e-learning and teachers' gender, academic qualifications, teaching experience and prior experience in e-learning. Through an investigation of 856 university faculty members, we found that student-level barriers had the strongest impact on the implementation of e-learning for ERT during Covid-19. Furthermore, teachers' academic qualifications and prior experience influenced the success of e-learning practices. Based on these results, we presented some implications with respect to student preparedness, curriculum modifications and institutional readiness for the successful implementation of ERT during Covid-19 or any similar future pandemics.
\end{abstract}

Keywords: Covid-19; e-learning; emergency remote teaching; Oman; higher education

\section{Introduction}

The Covid-19 outbreak has had a serious impact on educational systems around the world. The majority of higher education institutions cancelled face-to-face classes and embraced emergency remote teaching (ERT) in an attempt to maintain social distancing. With millions of students around the world having been affected by school and university closures during Covid-19 (UNESCO, 2020), many educational institutions implemented some type of ERT (Hodges et al., 2020). To curb the spread of coronavirus, the Omani government announced the suspension of all schools and universities on the 15th of March 2020, and 
consequently, most public and private institutions used what resources they had available to shift to ERT.

Technology integration for online and distance learning is a crucial component of providing quality education (UNESCO, 2014). Teachers at the tertiary level must be 'fluent users of technology' if they are to support student learning (US Department of Education, 2016, p. 34). Additionally, Trust (2017) argued that future teachers should be capable of using technology to enhance students' learning.

The shift to ERT has enabled higher education to provide instruction during emergencies; however, the shift has caused serious challenges (Crawford et al., 2020; Hodges et al., 2020). As many teachers were not prepared for the sudden shift to online instruction, they faced issues in preparing online content, adapting face-to-face materials, and learning new instructional pedagogies for online teaching and learning (Crawford et al., 2020; Dhawan, 2020; Rapanta et al., 2020). Gacs et al. (2020) and Karalis (2020) suggested that higher education institutions should provide sufficient support to their faculty during emergencies. Students faced issues with online learning during COVID-19 (Crawford, Butler-henderson, et al., 2020; Gaber et al., 2020; Zuo et al., 2020). Apart from teachers and students preparedness for ERT, institutions were not fully ready to shift to online instruction (Bao, 2020; Crawford et al., 2020).

Since ERT is mostly dependent on teachers' use of and competency in e-learning (Crawford et al., 2020; Demuyakor, 2020; Gacs et al., 2020; Hodges et al., 2020), it is essential that we measure the barriers to technology integration for ERT during Covid-19. Therefore, in this paper, we have sought to investigate the barriers faced by university teachers in using e-learning for ERT during Covid19 in Omani public and private higher education institutions.

In addition to advancing knowledge in e-learning and online pedagogy, the findings of this paper can inform higher education practitioners in overcoming challenges associated with online instruction during emergencies. Also, it can help institutions to better plan their instruction during similar pandemics in the future. People in charge of professional development can use the results of this study as a basis for needs analysis for teacher professional development and student training provisions.

\section{Literature Review}

ERT is a temporary shift of instructional delivery to an alternative delivery mode due to crisis circumstances (Hodges et al., 2020, p. 6). Remote teaching is not new, and it has been argued that teachers should, in fact, be prepared to teach and administer online courses (Baran \& Alzoubi, 2020; Crawford et al., 2020; Gacs et al., 2020; Hartshorne et al., 2020; Hodges et al., 2020; Karalis, 2020). While responses of higher education providers to Covid-19 differed, the majority of institutions in developed and developing economies chose to migrate to online teaching (Crawford et al., 2020; Hodges et al., 2020).

Karalis (2020) proposed a model that was intended to provide a good response to crises in education. He argued that a needs analysis that includes the needs of students, instructors and available resources, as well as considering the nature of 
the courses themselves, is required for the success of any emergency plan. Furthermore, Baran and Alzoubi (2020) proposed a human-centred model for transferring face-to-face courses online during Covid-19. Based on their model, they asserted that human-centred design models can enhance student empathy, engage students in pedagogical problem-solving and help them build a learning community (Baran \& Alzoubi, 2020). Despite these efforts, ERT is mainly aimed at ensuring the continuity of education during emergencies, which entails some sacrifices if it is to guarantee a rapid response to a crisis (Gacs et al., 2020; Hodges et al., 2020).

ERT requires technology integration, which poses challenges and difficulties for both teachers and students. Crawford et al. (2020) identified a variety of challenges that can hinder institutions in their migration to online education during ERT, including lack of infrastructure, teacher skillsets and readiness to design, offer and implement online teaching and learning. Apart from these challenges, many educational systems worldwide continue to lack online instruction strategies (Crawford et al., 2020). Moreover, Bao (2020) reported that higher academic institutions lacked the preparedness to shift to online teaching and learning during Covid-19, calling for systematic planning and investments from all sectors to ensure the ability to successfully shift to ERT. Similarly, Chang and Fang (2020) reported that teachers in higher education were not familiar with the teaching tools required for online teaching which posed serious negative impact on the implementation of ERT. Nevertheless, this unpreparedness, interruption and sudden shift, according to McMaster et al. (2020), can provide great learning opportunities for teachers.

Previous research has established a set of common technology integration barriers that have each been labelled, measured and rated differently, and that overlap on certain occasions (Schoepp, 2005). Common challenges include creating content for online spaces, learning new delivery tools, understanding online pedagogy, engaging parents, addressing student mental health issues, and attempting various pedagogical strategies to address both synchronous and asynchronous teaching and learning (Hartshorne et al., 2020, p. 138).

Alqudah et al. (2020) used a survey design to measure the perceptions and experiences of Jordanian academic ophthalmologists in e-learning for an undergraduate course during Covid-19. The study revealed some advantages of e-learning, including convenience, flexibility of time and place for both students and teachers, increased motivation of shy students and overcoming the circumstances of lockdown measures during Covid-19 (Alqudah et al., 2020). Though the majority of their sample viewed their e-learning experience during Covid-19 as positive and successful, Alqudah et al. (2020) did report some disadvantages of e-learning, such as lack of interaction, discomfort of teaching and learning without face-to-face interactions, and lack of practical and clinical training. The study also identified some limitations to e-learning during Covid19 , including poor infrastructure, shortage of e-learning training courses in ophthalmology, students' or teachers' poor e-learning skills and inadequate internet speed (Alqudah et al., 2020).

In another study using a survey design, Mailizar et al. (2020) examined the secondary school teachers' views of e-learning during Covid-19. This study 
found that student-related barriers (skills and knowledge, motivation and elearning infrastructure) had a strong impact on teacher implementation of elearning (Mailizar et al., 2020). Student-related barriers to e-learning implementation had a strong positive correlation with school-related barriers (i.e. availability of software and hardware, internet connectivity, policies, technical support) and curriculum-related barriers (i.e. content, assessments, elearning resources, curriculum alignment to online teaching and learning).

Due to the scarcity of research on this topic during Covid-19, for this study we relied on the large and growing body of literature that has investigated the barriers to e-learning implementation prior to Covid-19. Several studies (Assareh \& Hosseini, 2011; Naveed et al., 2017; Pelgrum, 2001) have identified various barriers to e-learning implementation. Despite differences in labelling and classifying these barriers, they were similar and overlapping. In general, the barriers can be classified into four main categories: student-related barriers, teacher-related barriers, curriculum-related barriers and institutional-related barriers. The issues related to students included lack of ICT skills, lack of elearning knowledge, lack of English language proficiency, lack of motivation, lack of technological infrastructure and poor assessment and online learning skills (Assareh \& Hosseini, 2011; Naveed et al., 2017; Pelgrum, 2001). Assareh and Hosseini (2011), Naveed et al. (2017) and Pelgrum (2001) also identified barriers related to teachers, including lack of ICT skills, lack of e-learning knowledge, instructor resistance to change, lack of time to develop e-courses, lack of motivation, difficulty in monitoring and assessing student learning and difficulty in integrating technology into teaching. With respect to curriculum, the literature identified a lack of sound instructional design, curriculum ambiguity, poor curriculum quality, unavailability of resources for e-learning and a mismatch between the existing teaching and learning process, current evaluation procedures, and the online curriculum (Assareh \& Hosseini, 2011; Naveed et al., 2017; Pelgrum, 2001). Finally, studies have also reported institutional-related barriers, such as inappropriate infrastructure, low internet bandwidth, lack of technical support, lack of financial support, lack of adequate policies and lack of training on e-learning and online pedagogy.

Several research studies have identified various determinants to successful elearning practices. Although gender was not a crucial factor influencing elearning use, research has reported that female teachers are more confident in utilising e-learning in their teaching (González-gómez et al., 212; Mahdizadeh et al., 2008). In addition to gender, teacher's academic qualification and prior experience in e-learning can affect the use of e-learning (Fryer \& Bovee, 2016; Jones, 2003; Sørebø et al., 2009; Wilson, 2012).

These studies highlight the barriers that teachers face when using e-learning in teaching and learning at various levels. These barriers hinder the teaching and learning process in ERT during Covid-19, as ERT is entirely based on either synchronous or asynchronous online teaching and learning (Hodges et al., 2020). Assareh and Hosseini's (2011) four-dimension classification of e-learning barriers (learners, teachers, curriculum and school) were used in this study. Since the context of the current study is higher education (i.e. colleges and universities), we changed the school classification to 'institution'. Learner- 
related barriers included insufficient e-learning knowledge and skills, limited accessibility and lack of motivation. Teacher-related barriers included insufficient knowledge and skills in e-learning, attitudes and beliefs towards elearning, lack of confidence and previous experience. The barriers related to curriculum that can hinder e-learning use included in this study are disparity between curriculum and assessment, f2f curriculum that does not have elearning components and complex tasks that cannot be delivered through an elearning system. Finally, we included the following institutional-related barriers in our study: e-learning infrastructure, policies and professional development in e-learning.

Our research is guided by the following research questions:

1. What barriers do teachers face in implementing e-learning for ERT during Covid-19 in Oman?

2. What is the relationship between each level of barrier to e-learning implementation?

3. Are there any significant differences between e-learning implementation barriers and teachers' gender, academic qualifications, teaching experience and prior experience in e-learning?

4. Are there any significant relationships between e-learning implementation barriers and type of institution?

\section{Methodology}

\subsection{Research Design}

The study employed a cross-sectional survey research design. Creswell (2018) defined survey research as "a set of procedures in quantitative research in which investigators administer a survey to a sample or to the entire population of people to describe the attitudes, opinions, behaviours, or characteristics of the population" (p.376). Elsewhere, Fraenkel et al. (2012) stated that using a questionnaire in survey research methodology could provide reliable, valid and generalizable quantitative and qualitative results.

\subsection{Research Instrument}

We developed a questionnaire consisting of three main parts to gather teachers' views on the implementation of e-learning during Covid-19. In Part A, the participants' demographic information, including gender, level of education, teaching experience, institution, specialisation, teacher certification and devices used for e-learning was obtained. The second part comprised 39 Likert-scale items that were grouped into the four main dimensions (teacher-related barriers, institution-related barriers, curriculum-related barriers and student-related barriers). We adapted the items included in the scale from various studies (Flack et al., 2020; Haney, 2002; Mailizar et al., 2020; Naveed et al., 2017) and added some items for the purpose of this research. Participants were asked to mark their responses on a five-level agreement scale ranging from strongly disagree to strongly agree. The third part included two open-ended questions that asked about other barriers that teachers faced in implementing e-learning during COVID-19 and about their suggestions for better online pedagogy during emergencies. 
Five academics from different institutions reviewed the questionnaire for clarity and relevance to ensure its content validity. Along with the questionnaire, a content validation form was provided for the reviewers. The questionnaire achieved satisfactory level of content validity (the content validity index for each item ranged between 0.8 to 0.92 across the five reviewers. In addition, we piloted the questionnaire with a group of university teachers from a private university in Oman who had experienced ERT during Covid-19. Twenty-seven teachers (55.9\% males, $44.4 \%$ females) completed the survey. The majority of the participants had a master's degree $(77.8 \%)$, while $22.2 \%$ had doctoral degrees. The sample included teachers from different specialisations, such as business, education, language and literature, information and communication technology and English language teaching.

To ensure the reliability of the research instrument, we computed Cronbach's alpha reliability coefficient in SPSS, which was found to be 0.88 . The reliability coefficient of the four dimensions ranged from 0.42 to 0.85 . Teacher-related barriers had a lower coefficient (0.42) compared to other dimensions of the questionnaire (teacher-related barriers $=0.75$; curriculum-related barriers $=0.77$; student-related barriers $=0.85$ ). Thus, we removed three items from the teacherrelated barriers dimension to increase the instrument's reliability. Once these items were removed, the coefficient increased to 0.89 .

The questionnaire was distributed to teachers using Google Forms ${ }^{\circledR}$. Participation in the study was voluntary. Although participants were not asked to fill out an informed consent, their submission of the questionnaire was regarded as their consent. Both researchers stored the data and the data was discarded once the data was analysed.

\subsection{Sample}

Following random sampling, we drew the actual study sample from public and private higher education institutions in Oman (teachers from public institutions, $\mathrm{N}=726$; teachers from private institutions, $\mathrm{N}=122$ ). Note that the numbers of teachers from each sector is not equal as there are more public institutions compared to private institutions in the country. The sample included 856 university teachers who experienced ERT during Covid-19 (63.3\% males, 36.7\% females). As shown in Table 1, the sample included teachers with various educational degrees. Exactly 70 of the participants held bachelor's degrees (8.2\%), 535 held master's degrees (62.5\%) and 251 held doctoral degrees (29.3\%). Although the teachers' teaching experience ranged from one to more than 15 years of experience, half of the sample had more than 15 years of teaching experience. The sample also included teachers from different specialisations, including social sciences, science, computer and information systems, education, business and management, engineering, mathematics and health. Four hundred and seventy-one of the teachers $(55 \%)$ had completed teacher preparation programmes, whereas 385 teachers $(45 \%)$ had not taken part in a teacher education programme. The majority of the participants $(83.2 \%)$ had some experience in e-learning prior to the implementation of ERT during Covid-19. During ERT, the teachers used various devices for online teaching and learning. 
Table 1: Demographic information of the research sample

\begin{tabular}{|c|c|c|}
\hline Variable & $\mathbf{N}$ & $\%$ \\
\hline \multicolumn{3}{|l|}{ Gender } \\
\hline Male & 542 & 63.3 \\
\hline Female & 314 & 36.7 \\
\hline \multicolumn{3}{|l|}{ Academic Qualification } \\
\hline Bachelor's Degree & 70 & 8.2 \\
\hline Master's Degree & 535 & 62.5 \\
\hline Doctoral Degree & 251 & 29.3 \\
\hline \multicolumn{3}{|l|}{ Teaching Experience } \\
\hline 0 to 5 Years & 32 & 3.7 \\
\hline 5 to 10 Years & 123 & 14.4 \\
\hline 10 to 15 Years & 237 & 27.7 \\
\hline More than 15 Years & 464 & 54.2 \\
\hline \multicolumn{3}{|l|}{ Specialisation } \\
\hline Social Sciences & 129 & 15.1 \\
\hline Science & 40 & 4.7 \\
\hline $\begin{array}{l}\text { Computer Science and Information } \\
\text { Systems }\end{array}$ & \multicolumn{2}{|c|}{ Systems } \\
\hline Education & 110 & 12.9 \\
\hline Business and Management & 88 & 10.3 \\
\hline Engineering & 283 & 33.1 \\
\hline Mathematics & 68 & 7.9 \\
\hline Health & 14 & 1.6 \\
\hline \multicolumn{3}{|l|}{ Institution } \\
\hline Public & 726 & 84.8 \\
\hline Private & 122 & 14.3 \\
\hline \multicolumn{3}{|l|}{ Teacher Certification } \\
\hline Yes & 471 & 55.0 \\
\hline No & 385 & 45.0 \\
\hline \multicolumn{3}{|l|}{ Experience in E-Learning Prior to ERT } \\
\hline Yes & 712 & 83.2 \\
\hline No & 144 & 16.8 \\
\hline \multicolumn{3}{|l|}{ Devices Used for E-Learning in ERT } \\
\hline Mobile/Handheld Device & 13 & 1.5 \\
\hline Computer/Laptop & 249 & 29.1 \\
\hline Both & 594 & 69.4 \\
\hline Total & 856 & 100.0 \\
\hline
\end{tabular}

\section{Findings}

We used a set of descriptive statistical tests including means, standard deviations, Spearman's correlation and one-way multivariate analysis of variance (MANOVA) to analyse the quantitative data. On the other hand, we used content analysis to analyse the qualitative data obtained through the openended questions. First, we familiarised ourselves with the data by reading the responses. Then, we defined grouping themes under which the initial data was classified. For question 1, we defined six emerging themes: policies and procedures, technological and infrastructure issues, student-related issues, curriculum-related issues, time-related issues and teachers' experience in online 
pedagogy. We then read the data, categorised it into six groups, and followed the same procedures to analyse the second open-ended question.

\subsection{E-Learning Implementation Barriers}

As indicated earlier, the barriers were classified into four main categories: teacher-related barriers, institution-related barriers, curriculum-related barriers and student-related barriers; the results of which are displayed based on this classification. Our descriptive results revealed that teacher-related barriers did not significantly hinder the implementation of e-learning during Covid-19 (see Table 2). Overall, the participants believed that e-learning was useful ( $M=$ $1.99, S D=1.11)$ and convenient $(M=2.24, S D=1.07)$ for ERT during Covid-19. The participants also held that they were confident $(M=2.12, S D=1.06)$ as they had sufficient knowledge $(M=2.15, S D=1.06)$ and the necessary skills $(M=$ $2.13, S D=1.03)$ to use e-learning during the pandemic.

Table 2: Descriptive results of teacher-related barriers

\begin{tabular}{|l|c|c|c|}
\hline Statement & \multicolumn{1}{|c|}{$\boldsymbol{N}$} & \multicolumn{1}{|c|}{$\boldsymbol{M}$} & \multicolumn{1}{|c|}{$S D$} \\
\hline $\begin{array}{l}\text { 1. I have sufficient knowledge to use e-learning for emergency } \\
\text { remote teaching during the Covid-19 pandemic. }\end{array}$ & 856 & 2.15 & 1.06 \\
\hline $\begin{array}{l}\text { 2. I have the necessary skills to use e-learning for emergency } \\
\text { remote teaching during the Covid-19 pandemic. }\end{array}$ & 856 & 2.13 & 1.03 \\
\hline $\begin{array}{l}\text { 3. I am confident in using e-learning for emergency remote } \\
\text { teaching during the Covid-19 pandemic. }\end{array}$ & 856 & 2.12 & 1.06 \\
\hline $\begin{array}{l}\text { 4. E-learning is useful for emergency remote teaching during } \\
\text { the Covid-19 pandemic. }\end{array}$ & 856 & 1.99 & 1.11 \\
\hline $\begin{array}{l}\text { 5. The use of e-learning for emergency remote teaching during } \\
\text { the Covid-19 pandemic is convenient for me. }\end{array}$ & 856 & 2.24 & 1.07 \\
\hline
\end{tabular}

Overall, institution-related barriers did not considerably obstruct the use of elearning (see Table 3). The participants confirmed that they had enough training $(M=2.22, S D=1.11)$ and technical support $(M=2.16, S D=1.16)$ from their institutions in implementing e-learning during the pandemic. Moreover, they agreed that the institutions provided them with a clear assessment policy $(M=$ $2.42, S D=1.13)$ and online conferencing tools $(M=2.21, S D=1.11)$ for synchronous communication with their students. However, the teachers reported that their institutions encountered challenges in monitoring the quality of online teaching $(M=2.94, S D=1.11)$.

Table 3: Descriptive results of institution-related barriers

\begin{tabular}{|l|c|c|c|}
\hline Statement & $N$ & $M$ & $S D$ \\
\hline 1. My institution has a policy for emergency remote teaching. & 856 & 2.38 & 1.14 \\
\hline $\begin{array}{l}\text { 2. My institution's policies and regulations support the use of e- } \\
\text { learning for emergency remote teaching during the Covid-19 } \\
\text { pandemic. }\end{array}$ & 856 & 2.21 & 1.12 \\
\hline $\begin{array}{l}\text { 3. My institution has a clear assessment policy for emergency remote } \\
\text { teaching during Covid-19. }\end{array}$ & 856 & 2.42 & 1.13 \\
\hline $\begin{array}{l}\text { 4. My institution has online conference tools for synchronous } \\
\text { communication with students and teachers. }\end{array}$ & 856 & 2.21 & 1.11 \\
\hline $\begin{array}{l}\text { 5. My institution provided technical support for e-learning use for } \\
\text { emergency remote teaching during Covid-19. }\end{array}$ & 856 & 2.16 & 1.16 \\
\hline
\end{tabular}




\begin{tabular}{|l|l|l|l|}
\hline $\begin{array}{l}\text { 6. My institution provided training on e-learning for emergency } \\
\text { remote teaching during the Covid-19 pandemic. }\end{array}$ & 856 & 2.22 & 1.11 \\
\hline 7. My institution allowed me to design my own learning experiences. & 856 & 2.33 & 1.07 \\
\hline $\begin{array}{l}\text { 8. My institution faced difficulty in monitoring the quality of online } \\
\text { teaching in emergency remote teaching during the Covid-19 } \\
\text { pandemic. }\end{array}$ & 856 & 2.94 & 1.11 \\
\hline
\end{tabular}

The curriculum-related barriers appeared to be more critical than the teacherrelated and institution-related barriers (see Table 4). The teachers reported that though learning and teaching materials and textbooks were available $(M=2.24$, $S D=1.01)$ and suitable $(M=2.43, S D=1.05)$, the nature of the courses made them difficult to teach online $(M=2.95, S D=1.22)$. They also stated that the courses included materials that could not be delivered properly online $(M=2.94$, $S D=1.11)$. Furthermore, the participants stated that some courses required faceto-face attendance for practical tasks $(M=2.52, S D=1.32)$ or settings that allowed for a community of learning, neither of which were attainable during elearning $(M=2.94, S D=1.14)$.

Table 4: Descriptive results of curriculum-related barriers

\begin{tabular}{|l|l|l|l|}
\hline Statement & $N$ & $M$ & $S \boldsymbol{D}$ \\
\hline $\begin{array}{l}\text { 1. Learning and teaching resources that are available in the e-learning } \\
\text { system are in accordance with the curriculum. }\end{array}$ & 856 & 2.24 & 1.01 \\
\hline 2. The textbooks that I use are suitable for e-learning use. & 856 & 2.43 & 1.05 \\
\hline 3. Student's assessments are in line with e-learning use. & 856 & 2.47 & 1.04 \\
\hline $\begin{array}{l}\text { 4. The nature of my course makes it difficult to be taught through e- } \\
\text { learning. }\end{array}$ & 856 & 2.95 & 1.22 \\
\hline $\begin{array}{l}\text { 5. My course has practical tasks that require students to attend in person at a } \\
\text { specific time. }\end{array}$ & 856 & 2.52 & 1.32 \\
\hline $\begin{array}{l}\text { 6. My course has many materials that cannot be conveyed online. } \\
\text { 7. The e-learning activities address different learning styles of students. }\end{array}$ & 856 & 2.98 & 1.27 \\
\hline $\begin{array}{l}\text { 8. My course requires a community of learning, which was difficult to build } \\
\text { in the e-learning system. }\end{array}$ & 856 & 2.56 & 0.99 \\
\hline
\end{tabular}

For the student-related barriers, the results (see Table 5) indicated that English language proficiency was a strong barrier $(M=3.00, S D=1.11)$ in the use of elearning for ERT during Covid-19. Lack of training $(M=2.99, S D=1.19)$, resistance to participation due to cultural norms $(M=2.96, S D=1.06)$, and inadequate internet connection $(M=2.95, S D=0.94)$ comprised the second, third and fourth barriers, respectively. The next most significant barriers were availability of devices (i.e. laptops and tablets) $(M=2.89, S D=1.07)$, lack of interest in using e-learning $(M=2.80, S D=1.04)$, lack of sufficient knowledge ( $M$ $=2.68, S D=1.17)$ and lack of necessary skills $(M=2.66, S D=1.13)$. On the other hand, ability to access the e-learning system $(M=2.55, S D=1.01)$, ability to progress $(M=2.49, S D=0.96)$, prior experience $(M=2.46, S D=1.29)$, raising questions $(M=2.43, S D=0.99)$, and completing course assignments $(M=2.30$, $S D=1.00$ ) were the least significant barriers, respectively. 
Table 5: Descriptive results of student-related barriers

\begin{tabular}{|c|c|c|c|}
\hline Statement & $N$ & $M$ & $S D$ \\
\hline 1. My students used e-learning prior to Covid-19. & 856 & 2.46 & 1.29 \\
\hline 2. My students have sufficient knowledge in the use of e-learning. & 856 & 2.68 & 1.17 \\
\hline 3. My students have the necessary skills for the use of e-learning. & 856 & 2.66 & 1.13 \\
\hline $\begin{array}{l}\text { 4. My students have devices (i.e. laptops and tablets) for the use of e- } \\
\text { learning. }\end{array}$ & 856 & 2.89 & 1.07 \\
\hline $\begin{array}{l}\text { 5. My students received training on the use of the e-learning system } \\
\text { prior to the Covid-19 pandemic. }\end{array}$ & 856 & 2.99 & 1.19 \\
\hline 6. My students are interested in using e-learning. & 856 & 2.80 & 1.04 \\
\hline 7. My students have an internet connection. & 856 & 2.95 & 0.94 \\
\hline 8. My students are able to access the e-learning system. & 856 & 2.55 & 1.01 \\
\hline $\begin{array}{l}\text { 9. My students' English skills are a barrier to using the e-learning } \\
\text { system. }\end{array}$ & 856 & 3.00 & 1.11 \\
\hline 10. My students are able to do online assignments during Covid-19. & 856 & 2.30 & 1.00 \\
\hline $\begin{array}{l}\text { 11. My students are able to raise questions and concerns during the } \\
\text { course in the e-learning system. }\end{array}$ & 856 & 2.43 & 0.99 \\
\hline 12. My students are able to progress in the course during Covid- 19. & 856 & 2.49 & 0.96 \\
\hline 13. My students find online assessment challenging. & 856 & 2.58 & 1.03 \\
\hline $\begin{array}{l}\text { 14. My students find e-learning hectic because of the number of } \\
\text { online courses during Covid-19. }\end{array}$ & 856 & 2.66 & 1.00 \\
\hline $\begin{array}{l}\text { 15. My students are resistant to participate in e-learning activities } \\
\text { due to cultural norms. }\end{array}$ & 856 & 2.96 & 1.06 \\
\hline
\end{tabular}

\subsection{Relationship between E-Learning Implementation Barriers}

We conducted an analysis of Spearman's correlation coefficient in order to pinpoint the relationship between each category of barriers to e-learning implementation. As Table 6 demonstrates, significant positive correlations existed among all levels, but the correlations were of different strengths. The results revealed that the strongest correlation was between teacher-related barriers and institution-related barriers $\left(r_{s}=.605, p=.000, N=856\right)$. Meanwhile, the association between teacher-level barriers and student-related barriers was moderate, but still statistically significant $\left(r_{s}=.553, p=.000, N=856\right)$. We found a moderate positive correlation between student-related barriers and institutionrelated barriers $\left(r_{s}=.548, p=.000, N=856\right)$ and between curriculum-related barriers and institutional-related barriers $\left(r_{s}=.444, p=.000, N=856\right)$. Moreover, there was only a weak positive correlation between student-related barriers and curriculum-related barriers $\left(r_{s}=.364, p=.000, N=856\right)$, and the lowest positive correlation among all the categories was between curriculum-related barriers and teacher-related barriers $\left(r_{s}=.271, p=.000, N=856\right)$. 
Table 6: The relationship between each category of barriers to e-learning implementation

\begin{tabular}{|l|l|l|l|l|}
\hline & $\begin{array}{c}\text { Teacher-Level } \\
\text { Barriers }\end{array}$ & $\begin{array}{c}\text { Institution- } \\
\text { Level Barriers }\end{array}$ & $\begin{array}{c}\text { Curriculum- } \\
\text { Level Barriers }\end{array}$ & $\begin{array}{c}\text { Student-Level } \\
\text { Barriers }\end{array}$ \\
\hline $\begin{array}{l}\text { Teacher-Level } \\
\text { Barriers }\end{array}$ & 1.000 & $.605^{* *}$ & $.271^{* *}$ & $.553^{* *}$ \\
\hline $\begin{array}{l}\text { Institution- } \\
\text { Level Barriers }\end{array}$ & & 1.000 & $.444^{* *}$ & $.548^{* *}$ \\
\hline $\begin{array}{l}\text { Curriculum- } \\
\text { Level Barriers }\end{array}$ & & 1.000 & $.364^{* *}$ \\
\hline $\begin{array}{l}\text { Student-Level } \\
\text { Barriers }\end{array}$ & & & 1.000 \\
\hline $\begin{array}{l}* \text { Correlation interpretation scale: .00-.19=very weak, .20-.39= weak, .40-.59 = moderate, .60- } \\
.79=\text { strong, .80-1.0 very strong. } \\
* * \text { Correlation is significant at the 0.01 level (2-tailed). }\end{array}$ \\
\hline
\end{tabular}

4.3 Differences in E-Learning Implementation Barriers in the Context of Teachers' Gender, Academic Qualifications, Teaching Experience and Prior Experience in E-Learning

We administered MANOVA to investigate any possible significant differences in e-learning implementation barriers in the context of the teachers' gender, academic qualifications, teaching experience, and prior experience in e-learning (see Table 7). There was a statistically significant difference between e-learning implementation barriers and academic qualifications: $F(8,1700)=4.51, \mathrm{p}<.05$; Wilk's $\Lambda=0.959$, partial $\eta 2=.021$. The MANOVA also revealed significant differences in e-learning implementation barriers due to teaching experience: $F$ $(12,2246)=2.07, \mathrm{p}<.05$; Wilk's $\Lambda=0.971$, partial $\eta 2=.010$. There were also significant differences with prior experience in e-learning: $F(4,851)=12.66$, $\mathrm{p}<$ .05 ; Wilk's $\Lambda=0.944$, partial $\eta 2=.056$. Furthermore, the results did not indicate any significant difference in e-learning implementation barriers resulting from gender: $F(4,851)=1.99, \mathrm{p}<.05$; Wilk's $\Lambda=0.991$, partial $\eta 2=.009$. Although the difference between these variable (gender, academic qualification, teaching experience, prior experience in e-learning) are minor, the results indicate that they influenced teacher implementation of e-learning during COVID-19.

Table 7: Results of the MANOVA

\begin{tabular}{|l|c|c|c|c|c|}
\hline \multicolumn{2}{|c|}{ Effect } & Value & F & Sig. & $\begin{array}{c}\text { Partial Eta } \\
\text { Squared }\end{array}$ \\
\hline Gender & $\begin{array}{c}\text { Wilks' } \\
\text { Lambda }\end{array}$ & .991 & $1.992 \mathrm{~b}$ & .094 & .009 \\
\hline $\begin{array}{l}\text { Academic } \\
\text { Qualification }\end{array}$ & $\begin{array}{c}\text { Wilks' } \\
\text { Lambda }\end{array}$ & .959 & $4.509 \mathrm{~b}$ & .000 & .021 \\
\hline $\begin{array}{c}\text { Teaching } \\
\text { Experience }\end{array}$ & $\begin{array}{c}\text { Wilks' } \\
\text { Lambda }\end{array}$ & .971 & 2.073 & .016 & .010 \\
\hline $\begin{array}{l}\text { Prior Experience } \\
\text { in E-Learning }\end{array}$ & $\begin{array}{c}\text { Wilks' } \\
\text { Lambda }\end{array}$ & .944 & $12.662 \mathrm{~b}$ & .000 & .056 \\
\hline
\end{tabular}




\subsection{The Relationship between E-Learning Implementation Barriers and Type of Institution}

We conducted a Spearman's correlation coefficient to investigate any possible relationship between e-learning implementation barriers and type of institution. The results revealed a very weak, but still statistically significant, positive association between curriculum-level barriers and the type of institution $\left(r_{s}=\right.$ $.071, p=.05, N=848$ ). This can be due to the different curriculum development and evaluation frameworks and guidelines implemented at different institutions. Also. Private higher education tend to have flexible curriculum guidelines where adapting and enhancing curriculum is accessible. However, curriculum change is more rigid and centralised in public higher education. Table 8 shows the relationship between e-learning implementation barriers and type of institution. The results of this test should be interpreted cautiously as the number of teachers in the sample were more from public institutions.

Table 8: The relationship between e-learning implementation barriers and type of institution

\begin{tabular}{|l|c|c|c|c|}
\hline & $\begin{array}{c}\text { Teacher- } \\
\text { Level } \\
\text { Barriers }\end{array}$ & $\begin{array}{c}\text { Institution- } \\
\text { Level Barriers }\end{array}$ & $\begin{array}{c}\text { Curriculum- } \\
\text { Level } \\
\text { Barriers }\end{array}$ & $\begin{array}{c}\text { Student- } \\
\text { Level } \\
\text { Barriers }\end{array}$ \\
\hline Institution & .000 & -.067 & $.071^{*}$ & .019 \\
\hline${ }^{*}$ Correlation is significant at the 0.05 level (2-tailed). \\
\hline
\end{tabular}

\subsection{Results of the Open-Ended Questions}

There was a good response rate for the open-ended questions in the questionnaire (the number of responses for question $1=590$, and the number of responses for question $2=582$ ). The first open-ended question encouraged participants to voice any issues they faced during ERT, while the second question allowed participants to provide suggestions to improve e-learning implementation practices for ERT during Covid-19.

The results revealed that teachers faced various issues with ERT during Covid19. First, the teachers reported facing issues related to technological infrastructure, including poor internet connectivity and lack of hardware and software for online teaching and learning. Consequently, these issues contributed to the failure of many of the online classes conducted during Covid19.

Our results also indicated some student-related issues. According to the teachers, many students encountered challenges due to poor network coverage, and students were not motivated to attend their online classes. Teachers attributed this issue to a lack of proper training on the use of live streaming platforms, course management systems and online learning skills and strategies. Moreover, the teachers reported issues with monitoring student attendance during the online classes. Some respondents reported that these difficulties were related to the students' joining and leaving classes frequently during the same online class due to internet connection issues. 
In addition, the results revealed that skills and knowledge of online teaching and learning were insufficient for some of the teachers. Accordingly, their inexperience in online pedagogy was reported in two contexts. First, the participants who faced these challenges were not competent in using the required applications for online teaching and learning, such as course management systems and video conferencing software. Second, they demonstrated insufficient knowledge of online pedagogy. In other words, they lacked knowledge of the teaching methods required to administer online instruction.

Furthermore, the participants reported issues with the curriculum. A common issue was that the existing face-to-face courses were not suitable for online teaching; the courses contained materials that were challenging for teachers to cover through online classes. Finally, the course assessments for the face-to-face classes were not suitable for online classes.

Our analysis showed that there were issues in relation to institutions' policies and guidelines. The participants reported that their institutions lacked online teaching and learning policies and guidelines. They also stated that their institutions were unable to monitor and assess the quality of e-learning during this period due to a lack of specific quality assurance measures for ERT. Meanwhile, only a few respondents mentioned issues with time; those who reported time as an issue stated that they found online teaching to be timeconsuming.

The teachers who participated in our study provided a variety of recommendations to enhance online teaching and learning through ERT during Covid-19. The majority of the respondents emphasised the need for proper student training, which would benefit the quality of both teaching and learning in the online context. They recommended student training in various areas, including video streaming software, learning management systems and screen and voice recording software.

The teachers also recommended enhancements to the technological infrastructure. Their recommendations can be divided into two main parts. Some of the recommendations focused on enhancing internet connectivity at both the national and institutional levels. In addition, the participants recommended providing and upgrading software, hardware and network facilities at the institutional level. Some teachers also recommended establishing video recording studios to aid in recording professional videos for online classes.

Furthermore, the teachers recommended some amendments to teaching and learning policies and institutional guidelines. Some of the teachers recommended establishing new policies that are specific to ERT, including changes to attendance policies, quality assurance and quality enhancement policies, and student support services.

Finally, the participants recommended a redesign of courses and assessments. Teachers who taught practical courses asserted the need to change assessment patterns to suit online instruction, and some of the teachers recommended 
including short quizzes prior to and after classes to ensure student readiness and to monitor and assess their understanding of the content.

\section{Discussions}

\subsection{Students preparedness for Emergency Remote Teaching}

The current study reveals that students were not prepared for ERT, and they demonstrated insufficient online learning skills, strategies and knowledge. Similar observations have been reported in previous research. Alqudah et al. (2020) identified poor e-learning skills, unpreparedness and inadequate internet accessibility for students as the main obstacles hindering the continuity of learning in the ERT period in Jordan. Research has also confirmed that student issues such as readiness, motivation, accessibility and equity negatively impacted e-learning practices during Covid-19 (Adnan \& Anwar, 2020; Bao, 2020; Hartshorne et al., 2020; Landrum, 2020; Mailizar et al., 2020). Prior Covid19 research has confirmed similar findings (Assareh \& Hosseini, 2011; Naveed et al., 2017; Pelgrum, 2001). Therefore, this suggests that students themselves might pose a serious challenge to e-learning implementation in an ERT context. Another possible explanation of this issue that should be considered, however, is that institutions may not have had sufficient time to prepare their students for the sudden shift to ERT.

\subsection{Curriculum and E-Learning Implementation during COVID-19}

The positive correlation between curriculum-related and institutional-related barriers signifies that the existing curriculum is not suited for ERT. A possible reason for this might be that most of the courses offered during ERT were not subject to sound instructional design due to the emergency situation. This is supported by Hodges et al.'s (2020) argument that online course design during ERT is often rushed with minimum resources, and little attention is paid to typical planning and preparation. This finding also confirms the work of Crawford et al. (2020) and Bao (2020), both of whom claimed that shifting courses to online delivery during Covid-19 lacked systematic course design and evaluation. Furthermore, recent research has pointed out the need for systematic planning when shifting to online instruction. Karalis (2020), for example, emphasised that piloting - piloting the new course, assessment and teaching materials - is an essential and integral part of shaping proper responses to emergencies in education. Meanwhile, along the same line of thought, Gacs et al. (2020) stressed the importance of a quick needs analysis to understand teacher and student needs in relation to technology, workload, accessibility, equity, readiness, motivation and prior knowledge.

\subsection{Institutional Readiness for Emergency Remote Teaching}

The positive correlation between teacher-related barriers and institution-related barriers can explain the unpreparedness for the shift to ERT during Covid-19. Our results confirm the lack of digital education policies and procedures at most higher education institutions in Oman. Additionally, the dearth of quality assurance measures and polices concerned with emergency teaching and learning negatively affected ERT practices. This finding relates not only to Omani higher education, but can be generalised to educational systems worldwide (see Crawford et al., 2020). Findings from the current research indicate the need for teacher professional development, especially since 
inadequate ICT skills in teachers has been reported as a crucial hindrance of elearning implementation (Alqudah et al., 2020; Assareh \& Hosseini, 2011; Bao, 2020; Chang \& Fang, 2020; Crawford et al., 2020; Naveed et al., 2017; Pelgrum, 2001; Sharpe et al., 2003).

\subsection{Other Influential Barriers}

Academic qualifications and teaching experience played a significant role in elearning implementation for ERT during Covid-19. Although teachers' academic qualifications and teaching experience have a positive effect on their implementation of e-learning, teachers advocated for training provisions specifically related to the ERT context. Previous research confirms the finding that prior experience and academic qualifications of teachers positively correlate to the successful implementation of e-learning (Cidral et al., 2018; Hartshorne et al., 2020; Mahdizadeh et al., 2008; Mailizar et al., 2020; Naveed et al., 2017; Reeves \& Pedulla, 2011).

Meanwhile, the type of institution did not lead to any significant differences in e-learning implementation for ERT. In other words, the experience of public and private educational providers was the same, which indicates that neither sector was fully prepared for the sudden shift to ERT.

\subsection{Requirements for Successful Emergency Remote Teaching}

The evidence from this study suggests that higher education institutions should pay attention to student training provisions. Higher education providers should consider providing and/or enhancing students' internet access to maximise their ability to participate in online learning. Although our findings relate to elearning implementation for ERT during Covid-19, they are applicable to normal teaching settings and face-to-face teaching that depends, to some extent, on elearning solutions. The current study also highlights the need for a national policy for digital delivery of higher education and a national policy for ERT. Although the shift to online instruction was accomplished rapidly, it is important that institutions follow a systematic plan for the shift to online instruction that considers the needs of both teachers and students. Additionally, it is necessary that periodic and quick evaluation of courses that are shifted online during ERT be implemented. While it might be argued that this may not be possible or feasible during exceptional circumstances, institutions should ensure that they review and pilot parts of their courses concurrently to online instruction. Student, teacher and parent feedback should also be considered when evaluating online instruction during ERT. Finally, this work demonstrates the importance of enhancing institutional technological infrastructure.

\subsection{Limitations and Future Research}

A number of limitations need to be considered. First, the study only included English-speaking teachers. The questionnaire was not translated into Arabic, which is spoken by many university teachers in Oman. Second, the study sample only included teachers. Including students in the study sample would have affected the conclusions we were able to draw, especially with regard to student-related barriers to e-learning implementation.

However, the findings of this study do bring up a call to teachers, institutions and policy makers to further investigate issues related to e-learning in ERT 
contexts. Future research should explore student training provisions in online learning during ERT and could also investigate the professional development of higher-education teachers in ERT contexts. Design-based research can be useful for designing and piloting teacher- and student-training programmes, and would be useful to assess institutions' readiness for online instruction and course design during COVID-19 and other unexpected emergencies in the future.

\section{Conclusion}

Using a cross-sectional survey design, we examined teachers' views on the implementation of e-learning in ERT during COVID-19. Student-related barriers had a strong impact on teachers' use of e-learning with teachers' academic qualifications and prior experience having a less significant impact on teachers' use of e-learning in ERT during COVID-19. The study recommends training programmes for both students and teachers to prepare them for handling learning and teaching in ERT contexts. In addition, the study recommends higher education institutions to adapt their curriculum to suite ERT. As teachers were not prepared for the sudden shift to ERT during COVID-19, higher education providers need to implement professional development provisions and amend their teaching and learning policies to suite the ERT context.

\section{References}

Adnan, M., \& Anwar, K. (2020). Online learning amid the COVID-19 pandemic: Students' perspectives. Journal of Pedagogical Sociology and Psychology, 2(1), 45-51. https://doi.org/10.33902/jpsp.2020261309

Alqudah, N. M., Jammal, H. M., Saleh, O., Khader, Y., Obeidat, N., \& Alqudah, J. (2020). Perception and experience of academic Jordanian ophthalmologists with ELearning for undergraduate course during the COVID-19 pandemic. Annals of Medicine and Surgery, 59(September), 44-47. https://doi.org/10.1016/j.amsu.2020.09.014

Assareh, A., \& Hosseini, B. M. (2011). Barriers to E-teaching and E-learning. Procedia Computer Science, 3, 791-795. https:// doi.org/10.1016/j.procs.2010.12.129

Bao, W. (2020). COVID -19 and online teaching in higher education: A case study of Peking University. Human Behavior and Emerging Technologies, 2(2), 113-115. https:// doi.org/10.1002/hbe2.191

Baran, E., \& Alzoubi, D. (2020). Human-centered design as a frame for transition to remote teaching during the COVID-19 pandemic. Technology and Teacher Education, 28(2), 365-372.

Chang, C. L., \& Fang, M. (2020). E-Learning and Online Instructions of Higher Education during the 2019 Novel Coronavirus Diseases (COVID-19) Epidemic. Journal of Physics: Conference Series, 1574(1). https://doi.org/10.1088/17426596/1574/1/012166

Cidral, W. A., Oliveira, T., Felice, M. Di, \& Aparicio, M. (2018). E-learning success determinants: Brazilian empirical study. Computers and Education, 122, 273-290. https:// doi.org/10.1016/j.compedu.2017.12.001

Crawford, J., Butler-henderson, K., Rudolph, J., Malkawi, B., Glowatz, M., Magni, P., \& Lam, S. (2020). COVID-19: 20 countries' higher education intra-period digital pedagogy responses. Journal of Applied Learning \& Teaching, 3(1), 1-20. https://doi.org/10.37074/jalt.2020.3.1.7

Creswell, J. W. (2018). Educational Research: Planning, Conducting and Evaluating Quantitative and Qualitative Research (6th edition). Pearson. 
Demuyakor, J. (2020). Coronavirus (COVID-19) and online learning in higher institutions of education: A survey of the perceptions of Ghanaian international students in China. Online Journal of Communication and Media Technologies, 10(3). https://doi.org/10.29333/ojcmt/8286

Dhawan, S. (2020). Online learning: A panacea in the time of COVID-19 crisis. Journal of Educational Technology Systems, 49(1), 5-22. https://doi.org/10.1177/0047239520934018

Fryer, L. K., \& Bovee, H. N. (2016). Supporting students' motivation for e-learning: Teachers matter on and offline. Internet and Higher Education, 30, 21-29. https:// doi.org/10.1016/j.iheduc.2016.03.003

Gaber, D. A., Shehata, M. H., \& Amin, H. A. (2020). Online Team- Based Learning Sessions as Interactive Methodologies During The Pandemic. Medical Education, March, 14198. https://doi.org/10.1111/medu.14198

Gacs, A., Goertler, S., \& Spasova, S. (2020). Planned online language education versus crisis-prompted online language teaching: Lessons for the future. Foreign Language Annals, May, 1-13. https://doi.org/10.1111/flan.12460

González-gómez, F., Guardiola, J., Martín, Ó., Ángel, M., \& Alonso, M. (212 C.E.). Gender differences in e-learning satisfaction. Computers \& Education, 58(1), 283290.

Hartshorne, R., Baumgartner, E., \& Kaplan-rakowski, R. (2020). Preservice and inservice professional development during the COVID-19 pandemic. Journal of Technology and Teacher Education, 28(2), 137-147.

Hodges, C., Moore, S., Lockee, B., Trust, T., \& Bond, A. (2020). The difference between emergency remote teaching and online learning. Educause Review, 7. https://er.educause.edu/articles/2020/3/the-difference-between-emergencyremote-teaching-and-online-learning

Jones, A. (2003). ICT and future teachers Are we preparing for e-learning. In IFIP Advances in Information and Communication Technology (Vol. 132). https://doi.org/10.1007/978-0-387-35701-0

Karalis, T. (2020). Planning and evaluation during educational disruption: Lessons learned from Covid-19 pandemic for treatment of emergencies in education. $\begin{array}{lllll}\text { European Journal of Education Studies, 7(4), } 2020 . & .\end{array}$ https:// doi.org/10.5281/zenodo.3789022

Landrum, B. (2020). Examining students' confidence to learn online, self-regulation skills and perceptions of satisfaction and usefulness of online classes. Online Learning Journal, 24(3), 128-146. https:// doi.org/10.24059/olj.v24i3.2066

Mahdizadeh, H., Biemans, H., \& Mulder, M. (2008). Determining factors of the use of elearning environments by university teachers. Computers and Education, 51(1), 142-154. https:// doi.org/10.1016/j.compedu.2007.04.004

Mailizar, Almanthari, A., Maulina, S., \& Bruce, S. (2020). Secondary school mathematics teachers ' views on e-learning implementation barriers during the COVID-19 pandemic: The case of Indonesia. Eurasia Journal of Mathematics, Science and Technology Education, 16(7). https:/ / doi.org/10.29333/ejmste/8240

McMaster, D., Veremu, M., \& Santucci, C. (2020). COVID-19: opportunities for professional development and disruptive innovation. Clinical Teacher, 17(3), 238240. https://doi.org/10.1111/tct.13175

Naveed, Q. N., Muhammed, A., Sanober, S., Qureshi, M. R. N., \& Shah, A. (2017). Barriers effecting successful implementation of E-learning in Saudi Arabian universities. International Journal of Emerging Technologies in Learning, 12(6), 94107. https:// doi.org/10.3991/ijet.v12i06.7003

Pelgrum, W. J. (2001). Obstacles to the integration of ICT in education: Results from a 
worldwide educational assessment. Computers and Education, 37(2), 163-178. https://doi.org/10.1016/S0360-1315(01)00045-8

Rapanta, C., Botturi, L., Goodyear, P., Guàrdia, L., \& Koole, M. (2020). Online university teaching during and after the Covid-19 crisis: Refocusing teacher presence and learning activity. Postdigital Science and Education, 2, 923-945. http://link.springer.com/10.1007/s42438-020-00155-y

Reeves, T. D., \& Pedulla, J. J. (2011). Predictors of teacher satisfaction with online professional development: Evidence from the USA's e-learning for educators initiative. Professional Development in Education, 37(4), 591-611. https://doi.org/10.1080/19415257.2011.553824

Schoepp, K. (2005). Learning and Teaching in Higher Education: Gulf Perspectives Barriers to Technology Integration in a Technology-Rich Environment. Learning and Teaching in Higher Education: Gulf Perspectives, 2, 1-24. http://www.zu.ac.ae/lthe/vol2no1/lthe02_05.pdf

Sharpe, R., Benfield, G., Roberts, G., Francis, R., Garrison, D. R., Anderson, T., Welsh, E. T., Wanberg, C. R., Brown, K. G., Simmering, M. J., Sun, P. C., Tsai, R. J., Finger, G., Chen, Y. Y., Yeh, D., Selim, H. M., Guri-Rosenblit, S., Chan, T.-W., Roschelle, J., ... Walton, G. (2003). What drives a successful e-Learning? An empirical investigation of the critical factors influencing learner satisfaction. Computers $\mathcal{E}$ Education, 49(4), 245-258. https://doi.org/10.1111/j.1470-3327.2005.00614.x

Sørebø, Ø., Halvari, H., Gulli, V. F., \& Kristiansen, R. (2009). The role of selfdetermination theory in explaining teachers' motivation to continue to use elearning technology. Computers and Education, 53(4), 1177-1187. https://doi.org/10.1016/j.compedu.2009.06.001

UNESCO. (2020). Global Education Coalition: Covid-19 Education Response. https://en.unesco.org/covid19/educationresponse/globalcoalition

Wilson, A. (2012). Effective professional development for e-learning: What do the managers think? British Journal of Educational Technology, 43(6), 892-900. https://doi.org/10.1111/j.1467-8535.2011.01248.x

Zuo, L., Dillman, D., \& Miller Juve, A. (2020). Learning At-Home During COVID-19: A Multi-institutional Virtual Learning Collaboration. Medical Education, March, 1-2. https://doi.org/10.1111/medu.14194 